GLOBAL JOURNAL OF EDUCATIONAL RESEARCH VOL 17, 2018: 1-8

COPYRIGHT@ BACHUDO SCIENCE CO. LTD PRINTED IN NIGERIA. ISSN 1596-6224

www.globaljournalseries.com; Info@globaljournalseries.com

\title{
EFFECT OF STRIKES ON MANAGEMENT AND PLANNING OF EDUCATIONAL ACTIVITIES IN NIGERIAN UNIVERSITIES
}

ODIM OTU OFFEM, ANNASTASHIA IWANG ANASHIE AND SOLOMON A. ANIAH

(Received 16, October 2017; Revision Accepted 12, February 2018)

\begin{abstract}
This paper examines the effect of strike on management and planning of educational activities in Nigerian universities. The meaning of strike was defined, and a brief history of strike in tertiary institutions in Nigeria was analyzed including the 2017 strike by ASUU. The causes of strikes were thoroughly explained. The effect of strike on management and planning of universities in Nigeria was also treated. It was concluded that Strike is a problem that has lingered for too long, yet nothing serious has been done about it. That management of strike in Nigeria requires the attention of both the government, educational managers, academic and non-academic staff, as well as other relevant stakeholders. That strike makes planning for universities' academic and non-academic activities to be very difficult. That everyone must play his or her role by abiding to agreements signed. That educational managers faces the challenge of re-planning educational activities, re-preparing the school calendar, re-assigning old task to new staff and not achieving certain long term goals due to the prolonged unaccomplishment as a result of the strike. Strike is an event that consumes and waste a lot of time which implies that urgent attention is needed to solve this problem. Recommendations were also made based on the observations from this paper.
\end{abstract}

KEYWORDS: Strikes, Management, Planning, Educational, Activities, Universities

\section{INTRODUCTION}

The goal of every university is to impart knowledge, skills, attitude, values and norms to learners in other to bring about development in the lives of every student and for national transformation and development. Accordingly, Amadi and Urho (2015) explained that the vision of Universities is to be pace-setting institutions in terms of learning, character building and service to mankind with a mission to produce competent and resourceful graduates with high moral standards in our society, and the total development of men and women in an enabling environment through appropriate teaching, research and service to humanity, influenced by the constitutional ethics and culture of our Nigerian state. Over the years, universities have played dominant roles in the developed world. Universities are usually in the forefront of any social, economic and political challenges, especially with the power of research being focused on areas that will promote human development and solve existential problems.

Education is as important as the air we breathe. It is the most important possession a person must have. Education is beneficial in many aspect of life especially, personal and social. It is the only possession that cannot be taken away from you. Education is important

Odim Otu Offem, Department of Educational Administration and Planning, University of Calabar, Calabar, Nigeria. Annastashia Iwang Anashie, Department of Educational Administration and Planning, University of Calabar, Calabar, Nigeria.

Solomon A. Aniah, Department of Educational Administration and Planning, University of Calabar, Calabar, Nigeria.

(C) 2018 Bachudo Science Co. Ltd. This work is licensed under Creative Commons Attribution 4.0 International license. 
because it will open up the windows of opportunities. In this competitive world having a good education is as important as the air we breathe because it is our weapon to conquer the world. Education will help you grow as an individual because the more knowledge you have the better understanding you will have in any given problem that will come your way. It will give you self-satisfaction and will boost your selfconfidence. As an individual I know it will help me a lot in many aspects of my life. It will give me a financial stability because I will be able to land a good job with a high paying salary. I will learn how to raise money and how to spend or invest it wisely. The more education I have the more respect and acknowledgement I will get from people. Knowledge is really important that is why we need to take it seriously. It is the strong weapon you can have to conquer this complex world. If you have a good education nobody can fool you and you will not tolerate any mistreatment from people. It will give you a better views in life if you are well educated. The benefits of education equip individuals of all ages with the skills and knowledge needed to be productive and successful global citizens. Educating citizens within poverty-stricken areas can be an effective way to address and eradicate global poverty.

According to Kagbaranen (2012) in (Amadi and Urho 2015), any government that does not encourage education of its youth is directly compromising the future of the nation. He also said that such government is not worth living. The quality of education offered by higher educational institutions in Nigeria in recent times has deteriorated substantially (Mohammed and Gbenu 2007 in Amadi and Urho 2015). This deterioration or incessant closures is due to strike actions. The effect of these repeated closures of schools and academic programs on students' learning effectiveness can better be imagined than described. University education in Nigeria has thus suffered serious setbacks as a result of teachers' strike actions. This has always subjected the students to pitiable conditions, disrupting academic programs, giving students' undeserved extension in their study years, poor students' concentration on academic programs and poor teacher-student relationships amongst others (Edinyang and Ubi, 2013).

Consequently, managing and planning academic, non-academic activities in Nigerian universities becomes very difficult or near impossible. Strike usually takes place in response to employee grievances, strikes are sometime used to pressure governments to change policies of universities infrastructural development and welfare of both Academic and non-Academic staff union of universities. Strikes are often part of a broader social movement taking the form of a campaign of civil resistance undertaken by unions during collective bargaining. Strike consists of workers refusing to attend word and picketing outside the workplace to prevent or dissuade people from working in their place or conducting business with their employer. Students strike sometimes supported by faculty not attending schools, such strike is intended to draw media attention to the institution so that the grievances that are causing the student $\mathrm{s}$ to strike can be aired before the public. Though this usually damages the institutions or government public image (Edinyang and Ubi, 2013).Disruptions in academic programs serve as non-motivational factor to the students. It discourages them from learning. It is not surprising therefore that during strike actions, most students are seen involved in diverse activities such as sexual immorality, cyber scam, pool betting, unnecessary gossips, watching of films and reading comic materials for entertainment purposes rather than reading their books. In the long run, they soon forget about academics and are no longer prepared for class activities which negatively affect their learning capability (Chijioke 2013 in Omotere 2014). It has been revealed that students across various institutions of higher learnings in Nigeria are constantly faced with industrial actions either by the Academic or Non-Academic Staff (Admin 2012), the disagreement or lack of understanding between government and academic community often result in deadlock that usually disrupt academic calendar.

Odubela (2012) in Omotere (2014) concluded that an effective learning or an enhanced academic performance is achieved by successful covering of the course outline timely and before the examination. This is rarely achieved with strike action in place. Given the above review, it can be deduced that strike by either Academic staff Union of Universities, Non Academic Staff Union or any other such trade union, has adverse effect in the proceedings of academic and non-academic activities of universities in Nigeria. When school activities are disrupted, it becomes more difficult for educational managers to plan, direct, and co- 
ordinate educational activities in Nigeria. What effect has strike on the management of schools and how can educational managers effectively make good decisions and manage educational activities that will promote organizational goal attainment during these periods of strike? This paper seeks to explain the history, causes and effect of strike in the management of Universities in Nigeria.

\section{WHAT IS STRIKE?}

Strike, according to Chijioke (2013) "is an organised work stoppage by a body of workers to enforce compliance with demands made on an employer or a group of employers." It is an aspect of industrial conflict used by workers to express their grievances. It is a collective, organized, cessation or slowdown of work by employees, to force acceptance of their demands by the employers Amadi and Urho (2015).Strike is workers' refusal to work as protest for inadequate service or poor condition. In the education sector, teachers' strike can be compared to students' examination malpractice, corruption and other social vices in the society. Strike is a social ill not different from corruption because it eats into students' time which makes it difficult for students to be fully and properly 'baked' within the designated educational time frame. As a result, 'products' that are ill equipped in both character and learning are turned out to the society (Edinyang and Ubi, 2013). Parker(2012) describes a strike in labour or employment relations as a combined action of a group of employees, thereby withdrawing their labour totally or partially, with the purpose of persuading an employer to succumb to their combined demands.

From the foregoing, it can be said that strike is a deliberate action or decision taken by a group of individuals with the same interest towards their employers to stop working for several reasons. It is withholding normal work activities by individuals due to inability of such workers to reach a consensus with their employers.

However, strike occur due to so many reasons such as negotiation, procedural matters, probationary period of service, disciplinary procedure, principles of redundancy, professional examinations, various unpaid claims, staff loan, pension and gratuity scheme; salaries and wages, leave, acting allowance, inconveniences allowance, out of station expenses, medical scheme, sickness benefit etc (Ohiwerei and Omo-Ojugo, 2008).

\section{BRIEF HISTORYOF STRIKES IN NIGERIA}

The history of strike in tertiary institutions in Nigeria dates back to $20^{\text {th }}$ May, 1980 , when a trade disputes was declared with the Governing Councils of Universities in Nigeria, which demanded improved funding of the universities, academic freedom, autonomy, as well as the setting up of a special body, to review the conditions of service of the universities' staff. Early in 1992, members of Academic Staff Union of Universities(ASUU) declared an industrial dispute, overgross underfunding of universities in Nigeria, poor conditions of service of the academic staff, university autonomy, as well as the need for academic freedom. The strike lasted for nine months nationwide but at the end, ASUU was proscribed while a separate Salary Scale tagged 'University Academic Staff Salary (UASS) was approved by government, which triggered another strike by the Senior Staff Association of Teaching Hospitals, Research Institutes and Allied Institutions (SSATHRIAI) and NonAcademic Staff Union (NASU)members, which sought parity in salary with the Academic Staff Union (ASUU).

In February, 1993, the University Academic Salary Scale(UASS), earlier approved for ASUU members, was cancelled while an Elongated University Salary Structure(EUSS) was approved in its replacement. Consequently, 1993/94 academic session was scrapped in most universities. On $3^{\text {rd }}$ May, 1993, members of ASUU declared another strike, which lasted for five months and challenged the cancellation of the University Academic Salary Scale (UASS). In 1994, ASUU declared another politically motivated strike, which demanded the actualization of June $12^{\text {th }}$ Presidential Election, won by Chief M.K.O Abiola, as well as proper funding of education. The report of the Monitoring Committee on federal tertiary institutions in Nigeria, in March, 2002, indicates that between 1992 and 1999, there were seven strike actions including industrial strike, trade dispute, internal strike, and nationwide strike.

On 22 June, 2009, the National Executives of ASUU declared a total and indefinite strike, to compel Federal Government to sign the agreement reached with ASUU on the re-negotiation of June, 2001 FGN-ASUU 
Agreement. In October, 2010, all the Universities in the Southeast zone of Nigeria embarked on an indefinite strike, where they demanded for the implementation of the agreements signed with ASUU, particularly on salary and allowances. A report in the also indicated that all the tertiary institutions in Kwara State (one of the 36 States in Nigeria) embarked on a strike, demanding for one hundred percent implementation of the Consolidated Polytechnics and Colleges of Education Salary Structure (CONPCASS) and the Consolidated Tertiary Institutions Salary Structure(CONTEDISS), effective from January, 2009. The Academic Staff Union of Universities(ASUU) declared a strike over the non-implementation of the agreements reached with Federal Government since year 2000. The strike lasted for almost six months and was suspended during the last week of December, 2013.

In November 2016, ASUU went on a one-week warning strike. That strike was a culmination of the persistent call on the Federal Government to address issues bordering on how to re-position the Nigerian university system, based on the desire to deal with the rot and decay in the system. An understanding was reached on the issues leading to the warning strike, but government went to sleep after the strike action was suspended.

ASUU embarked on an indefinite strike on August 14, 2017 due to government failure to redeem the terms of agreement signed in 2009 and Memorandum of Understanding (MoU) endorsed by both parties in 2012. The strike lasted for over a month and was temporarily called-off on the $17^{\text {th }}$ September 2017 pending when the government will implement the new agreement. Areas of the new agreement included funding for revitalization of public universities and the issue of Earn Academic Allowances, the issue of University Staff Schools and the implementation of the judgement of the National Industrial Court, National Universities Pension Management Company and guidelines for pension matters for Professors. All these are various Strike regimes that have befallen tertiary institutions in Nigeria

\section{CAUSES OF STRIKES IN NIGERIA.}

It is popularly said that "there is no action without a course", or "there is no smoke without fire." Strike does not occur in a vacuum, there are many reasons why workers engage in strike which may include; dissatisfaction with company policy, wrongful discharge or dismissal of workmen, withdrawal of any concession or privilege, hours of work and rest intervals, dispute connected with minimum wages, Political views on conflicts between the working class and their employers; and Introduction of new technology which affect the traditional ways of doing business in particular company.

1. Poor and inconsistent Payment of Salaries; University workers are often underpaid and most times the Government pays part salaries to lecturers. Lecturers are not happy due to the fact that many politicians go home with bags of money even when such politicians are not as educated as they. According to Amadi and Urho (2015), the underpayment of university staff vis-à-vis their counterparts in other economic sectors and the discriminating salary structure between the Academic Staff Union of Universities (ASUU) and the Non- Academic Staff Union of Universities (NASU) have been a major cause of their dissatisfaction.

2. Poor conditions of Service: Teachers are not offered additional incentives and working conditions as their counterparts. For example, those in health and other sectors receive extra payment for hazards in their jobs but such cannot be heard of in education even though there are also hazards in discharging teaching duties. According to Amadi and Urho (2015), this condition of service or employment include such features as working conditions (i.e. working environment, hours or work, over time shift work, flexible working hours), fringe benefits, (i.e. sick pay, subsidized meals, pension scheme, company goods at a discount, company cars) and application of fair judicial procedures. For instance, University lecturers could demand for the immediate reinstatement of their colleagues who have been unfairly dismissed or punished by government while acting on their behalf, failure of which might result in strike action.

3. Political interference in Education: Many times the university has no autonomy to operate as an entity without the leaders in political offices trying to use their positions to influence activities. Schools are not allowed to make educational decisions without such interference. This creates problems when 
educational administrators refuse to buy into the idea of such leaders. Amadi and Urho (2015), noted that, the seats of Vice-Chancellor and Registrar of universities are keenly contested for. It was noted that one of the reasons why people leave universities is because there is a lot of interference in academic freedom. Sometimes, however, government intervention is inevitable where there is an ongoing rift among university staff.

4. Poor funding of the education sector: The United Nations in an attempt to improve education in Nigeria, recommended that 26 per cent of the Nation's budget should be channeled into the education sector. It has been noticed that the Government has never met such conditions, this further results in many universities being under funded and poor infrastructural supplies, poor payment of salaries and poor maintenance of existing plants. Strike may be caused by this if staff get upset with the poor work flow and poor remuneration pattern. Amadi and Urho (2015) noted that the annual budget on education is low compared to the budget made for other things in the state. For example, budget for elections and numerous huge amount of money mismanaged could be responsible for the existing poor teaching and learning facilities in our universities and poor quality graduates produced.

5. Non-Compliance to Agreement: Workers and employers usually reach agreements after negotiations but in some cases one party may refuse to honor the agreements. For example, Since December 2002 ASUU has been on total strike following Federal Government failure to honor the agreements it reached with ASUU in 2001 over proper funding. The 2017ASUU strike occurred due to Government failure to comply with already signed agreements and memorandum of understanding (MoU) in 2009 and 2013.

\section{Unnecessary Delay in Payments of} Salaries and other Emoluments: When

there is a delay in payment of salaries without a justifiable reason for such delay, workers may embark on strike for such salaries to be paid. Ezeagba, (2014), noted that in Nigeria many organizations always delay or refuse to pay their workers' salaries and other emoluments even when the organizations concerned have sufficient funds to pay. For example, secondary schools in
Anambra state have been on strike for over a year for non-payment of salary.

\section{EFFECT OF STRIKES ON MANAGEMENT AND PLANNING OF UNIVERSITIES IN NIGERIA}

Strike actions affect the activities of the entire university management including planning and effective decision making by disrupting academic schedules, programmes and plans.

According to Otobo (2005), the general effect or impacts of strikes and lookout on workers and management, (private and public may be usefully examined at three levels, all of which would be affected by actual conduct situation, duration of conflict, and the agreement, duration of conflict and the agreement reached. These three levels are the social - psychological, political and economic effect.

According to Igbaji (2009), in Amadi and Urho, (2015), an industrial relation system, conflicts (strikes) arise between workers and managers chiefly because of their different ideologies and opposing interests. Students across various institutions of higher learnings in Nigeria are constantly faced with industrial actions either by the Academic or Non-Academic Staff, the disagreement or lack of understanding between government and academic community often result in deadlock that usually disrupt academic calendar. In 1997 and 2000, statistics showed that federal government expenditure on education was below $10 \%$ of overall expenditure. The fervent interruption of our education system is not limited to higher institution. Primary and secondary school teachers have embarked on strike in recent times to voice their grievances, too.

The indefinite strike action embarked upon by the Academic Staff Union of Universities (ASUU) 11th March 2013 crippled academic activities in nearby Universities like the University of Port Harcourt (Uniport) and the newly established Rivers State University of Education (UOE). The industrial action lasted for at least six months, it was called off on 5 Dec. 2013. Lecture halls were empty; students were just loitering around for a whole session (Amadi and Urho, 2015).

During strikes, some workers or the entire workers stop working for a period of time. The duration of time is dependent on how the parties involved are able to reach a consensus. No matter how long or short a strike may last, it has adverse effect as managers are left without a 
portion or none of her workers. For example, the 2017 industrial actions by ASUU, NASU, SANU and NAAT affected the plans and management of many public Universities in Nigeria. ASUU struck for over a month in 2017 and this led to all the academic staff withdrawing from duties, and many students returning home, travelling or looking for a temporary jobs. In university of Calabar for instance, the management had planned the school calendar for the session with second semester exams scheduled and many other activities put in place. These activities including the examination were hindered without being achieved. The Non - Academic staff struck two weeks to when Academic staff had their agreement reached with the Federal Government to further put more salt to a salty situation.

Managing and planning for University activities after strike is a tedious task as managers are made to make hasty decisions, rush certain activities, re-plan, re-assign certain tasks, re-organize or take new dimensions to meet up with time. This may in turn have an effect on students, teachers and university performance as many students will be under taught, many lecturers will not be able to cover lost grounds within the limited time they are to rush over activities and the goal of the university to produce graduates that will compete with the rest of the world might be defeated if this occur several times.

According to Amadi and Urho, (2015), most academic activities for school year are distorted. This is one of major cause of producing unqualified graduate who are deficient in their fields of study. In the same vein, students who are supposed to do a four year course end up spending six years in the school. Such strike periods also have the tendency of leading undergraduates into some social vices like prostitution, oil bunkering etc. "An idle man" they say "is the devils workshop" they say. There is therefore, the need for a re-evaluation of the education sector.

Strike poses difficulty in record management. Some workers (Academic or nonacademic) in charge of record keeping may, misplace, lose or forget the locations of students' vital records in their possession due to the period away from duties as a consequence of strike. The management functions include; planning, organizing, staffing, directing, coordinating, reporting and budgeting. It might interest you to know that all the functions of management cannot be performed during strike periods where a significant portion of the workforce and students are absent if not all. Re-planning school activities after strike is a very difficult exercise because it involves collapsing other plans that were not successfully implemented prior to the strike.

According to Adesina (2008), the immediate effect of the depressing working conditions in university is mass resignation, departure of hard-working colleagues to North America, Western Europe, the Middle East and even to African Countries with less buoyant economics than oil-rich Nigeria. Most lecturers are completely disillusioned with the gross neglect of successive governments of the educational sector and government hard-line posture to their legitimate demands. They cannot plan their schedule such as the period to proceed on sabbatical leaves. It is unfortunate that government has not really evaluated the financial loss it incurs as a result of incessant strikes in our educational institutions as it does in other sectors of the economy.

Oladipo (2012) stated that strike would result in the academic calendar being compressed and parts of the curriculum skipped, some topics would not be treated and the student would have to write the exams like that, resulting in poor performance and decline in quality of education. The long term effect of the strike would be profitable to all, when government meets the demands of the academic staff union of universities. The immediate effect of the strike is obviously adverse. It would be very tough. Programmes would have to be adjusted, lectures, tests, exams, meetings and so on. It is unfortunate that government had not maintained the agreement signed with ASUU in 2009 despite a warning strike in September, 2012, strike in 2013 which led to the strike in August 2017.

Strike is a very sad situation that makes many educational managers to wander about in search for new ways to effectively manage academic matters during and after these strike regimes. Though strike has a lot of effect, it is a means through which the parties involved gets to know how one partner feels as a result of another's unwillingness or inability to comply to agreed terms. Nigeria keep battling with Macroeconomic problems such as poverty, unemployment, under development but to mention a few, due to incessant strikes. When the management of universities cannot effectively 
plan during these periods, goals are not attained. The academic calendar on the other hand, does not get exhausted, learners become half-baked as a consequence, and in the end there is a mismatch between what the society demands from education and what education supplies to the society. This further has a resulting effect on organizational goal attainment and national development.

\section{CONCLUSION}

Strike is a problem that has lingered for too long, yet nothing serious has been done about it. Management of strike in Nigeria requires the attention of both the government, educational managers, academic and non-academic staff, as well as other relevant stakeholder. Strike makes planning for universities' academic and nonacademic activities to be very difficult. Everyone must play his or her role by abiding to agreements signed. Educational managers faces the challenge of re-planning educational activities, re-preparing the school calendar, reassigning old task to new staff and not achieving certain long term goals due to the prolonged unaccomplishment as a result of the strike. Strike is an event that consumes and waste a lot of time which implies that urgent attention is needed to solve this problem.

\section{RECOMMENDATIONS}

The following recommendations have been made from this study:

1. The government should respect every agreement entered in to and maintain consistently, their terms of agreement.

2. More funds should be allocated and channeled into education sector from the national budget in every fiscal year.

3. The government should provide all relevant materials, facilities, equipment and other school plant necessary for the smooth running and management of universities in Nigeria.

4. All relevant trade unions related to education should ensure that proper communication between them and the Government are established, and make efforts to resolve issues using other techniques such as dialogue rather than embark on strike all time.

5. During strike, the staff should ensure that all the purposes for which they struck are met before thinking of calling off the strike. This will help reduce the frequency of strike occurring and re-occurring.

6. All educational managers especially those managing universities should ensure that proper remuneration, and motivation techniques are used to boost the morale of other staff.

7. Educational Managers should make plans that are short term in nature. They should also ensure that proper supervisory techniques are used to check the effectiveness and efficiency of every academic and non-academic staff so that the effect of strike will not be so much on lectures as they will have delivered many lessons already before the strike.

\section{REFERENCES}

Adesina, J., 2008. Nigerian striker's salaries stopped / General / Times Higher Educati on.www.timeshighereducation.co.uk/new s.

Amadi, E. C and Urho, P., 2015. Educational management planners' view of strike action and its effects on educational management in Universities in Rivers state. Singaporean journal of business economics, and management studies, 4 , (7): $45-55$.

Edinyang, S. D and Ubi, I. E., 2013. Effect of strike action on human development among social Studies secondary school students in Uyo local government Area of Akwa Ibom State, Nigeria. Global journal of human resource management, 1, (2): $1-8$.

Ezeagba, E. C., 2014. Effects of strike cost on economic development in Nigeria. International journal of arts and humanities (IJAH), 3, (3): $26-34$.

Igbaji, P., 2001. Industrial relation system between workers and management strike.

Ohiwerei, F. O and Omo-Ojugo, M. O., 2008. Causes of conflict in banking industry. 
International business management. Medwell Journal. 2, (4): $132-144$.

Oladipo, B., 2012. Unplanned breaks affect students' ASUU strike: Daily news October 21, 2012. Nigeria daily post Nigeria newspaper online.

Omotere, T., 2014. Effects of asuu strikes on the academic performance of university students. M.Ed. Thesis, Ego Booster Books.
Otobo, 2005. Reading in industrial relation in Nigeria. Lagos malt House Press Ltd.

Parker, C., 2012. Labour law in Namibia. Windhoek: UNAM Press. 
